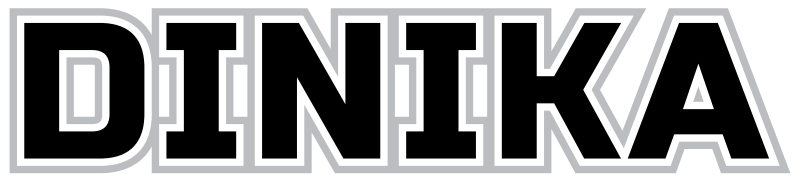

Academic Journal of Islamic Studies

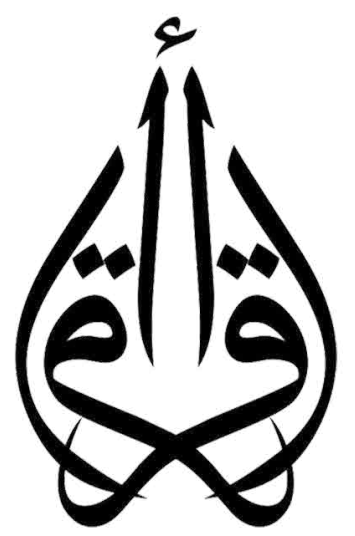


Volume 4, Number 3, September - December 2019 ISSN: 2503-42I 9 (p); 2503-4227 (e)

\section{DINIKA}

Academic Journal of Islamic Studies

\section{Table of Contents}

\section{Main Articles:}

Muslimab Beauty Veiling, Piety and Commodity in the New Indonesian

Public Sphere

Yuyun Sunesti

Competing Identity and Culture: The Formation of Forum Lingkar Pena and Komunitas Matapena in Indonesia

Nor Ismah

Ria Ricis and New Platform of Islamic Popular Culture

Wahyudi Akmaliah

\section{Articles:}

Perseteruan Memori Kolektif Kontestasi Islam dan Politik di

Tasikmalaya Pasca-Orde Baru

Amin Mudzakkir

Qital: Reinterpretasi Pendekatan Humanis

Ana Rahmawati, Azzah Nor Laila

The Characteristics of Philosophical Knowledge of The Qur'an and Prophetic Revelation According to Muni Laswad in His Book Islâm al-Falâsifa

Muhammad Makmun, Dessy Yanti Srie Budiningsih 


\title{
Muslimah Beauty Veiling, Piety and Commodity in the New Indonesian Public Sphere
}

\author{
Yuyun Sunesti \\ Universitas Sebelas Maret Surakarta \\ email:yuyun_sunesti@staff.uns.ac.id
}

\begin{abstract}
This paper explores the veiling issues and the negotiation of piety among women in Komunitas Muslimah Beauty of Detik Forum. This paper examines to what extent this online community discusses hijab as fashion and piety? what the basis of the arguments for negotiating them? and how is piety constructed through commodity by women in that forum? The answers to this question are important to understand because they examine the assumption considering the lack of connection between piety and veiling when both are more materialized in such of commodity fetishism. To do this, I analyze the online discussion within the Komunitas Muslimah Beauty in detik.com website. The findings of the paper inform both sociological understanding of the rise democracy in terms of the public sphere as well as the negotiation of women in their effort to connect veiling and piety within their online discussion.
\end{abstract}

Keywords:

Piety, Public Sphere, hijab, muslimah

\section{Introduction}

Veiling has become a concern in many Muslim communities when talking about women's identities. Historically speaking, veiling has been practiced by Muslim women in the prophet Muhammad's era to differentiate Muslim women and non-Muslim women. At that time, veils were worn to protect women from insults and harassment (Hassan 2003: 188). Since then, veiling has been practiced by many more Muslim 
women with various motives and models. It has been argued that, in Indonesia, the significant growth of veiling phenomenon began after the Reformation era where the euphoria of people's expression has become more public. Veiling has been then transformed from what Brenner's explanation that veils are worn as a kind of women conversion from bad past to better future in religious terms to more complex reasons, purposes and appearances (Brenner 1996: 673-697). Veiling has been more publicly seen than in previous eras, thus showing the freedom for women's choices in expressing their religious identity.

However, along with these Islamic symbols has been a more public, the debate about the fashion of veiling has also emerged. Some argued that more fashionable veiling can reduce the religious value of veiling due to its neglect of the basic principle of veiling as modesty and protecting women from harassment. Some also argued that the choice of women to adopt more fashionable veiling has been a kind of women's negotiation to present the modern era urging women to be more modern and at the same time they can keep their pious appearances. This debate come up in everyday life of women's discussion as well as in the online public spheres.

It has been argued that the significantly different characteristic of the public sphere can be found in the more advanced communication media, principally the internet. It is widely held belief that the internet is responsible for an incredible transformation in societal debate and the formulation of new social movements which is central to sociologists reconceptualizing the idea of the public sphere for analyzing the contemporary world. Online bulletin boards, also known as discussion boards or Internet forums, is one of the types of this online public sphere which produces flowing debates among members. Barton argued that online discussion forums can easily build a communication based on quick responses as well as critical debate among its members (Barton 2005: 182). 
This paper investigates the discussion within Muslimah Beauty Forum in detik.com website. Detik is one of the most prominent online news websites in Indonesia representing the secular background of media communication as well as the variety of forum members based on the topic discussions and Detik itself as secular website. It claims to have 15 million readers (iklanbaris.detik.com 2009) with approximately 2 million readers a day (id.shvoong.com 2009). Detik also has 308,043 detik discussion forum registered members in 2009 (forum.detik.com 2009), and in 2014 it has 1,019,667 members, 829,991 threads, and 27,870,191 posts (forum.detik. com 2014). In addition, Muslimah Beauty is a new forum discussion established in 2011 as one of the forums under community sub-forum within Detik forum and currently has 61 threads with 1258 posts ranging from May 2012 to May 2014 (forum.detik.com 2014).

Muslimah Beauty was created by Alivalive, an online name, who posted in the first time in October 13, 2011 informing the opening of the community. As the founder of the forum Alivalive said that this community was established after the event of Muslimah Beauty Award 2011 held for the first time in Jakarta initiated by Detik Forum. She pointed out that this community was created for bridging Muslimah to build sillaturrabmi (relationship) and share their information and knowledge without border of space, time and age. To join this forum, she explains that Muslimah must register in Detik Forum first and then those who give comment on this forum will be automatically becoming the member of Komunitas Muslimah Beauty (forum.detik.com 2014).

Although originally Muslimah Beauty is an online discussion, it has had offline activities where members can meet each other and create several activities such as the hijab hunt final contests where in 2013 was held in Jakarta and social activities such as restoring a beautiful mosque in Jakarta on February 11, 2012 (forum.detik.com 2014). Originating from online discussion, Muslimah Beauty has now a foundation founded and chaired by 
Eka Shanty namely Muslimah Beauty Foundation (MBF). Shanty said that $\mathrm{MBF}$ is non-profit organization having a vision in developing Indonesian potential muslimah and the owner of hijab hunt license held by online which is the first time in the world. She also notes that the hijab hunt contest is a form of appreciation for hijabers who have high achievements s although wearing hijab in their everyday life (forum.detik.com 2014). Hijabers aged eighteen to twenty-five having good achievement and ability in English and reading Al-Qur'an can register to compete in this contest (forum.detik.com 2014).

In addition, content analysis will be used to analysis the data from the online forum discussion. The method is chosen because the text in which messages in online discussion forums will be analyzed is very large and there needs to be an excerpt in quantified categories in order to achieve the meaning of the messages. To do this, I will categorize the discussion into several theme which each theme consists of topics having similar or related topic discussion. After that, I will choose several topics which have significant responses from the members as well as the availability of the debate on the piety and beauty themes. By using mix method of quantitative by making table of categorization and qualitative by presenting several members' comments, the research will comprehensively portray the debate happened in the forum.

Since the discussion of this paper is questioning the relation between veiling, piety and commodity, the various concept of piety will be elaborated. Sociological understanding and common-sense show that religiosity has no monolithic meaning (Hassan 2003: 40). It has different meaning for different people. Based on his research in three countries, Pakistan, Egypt and Indonesia, Hassan found that piety cannot be simply defined as to what extent people do their religious worship, but also should consider an ethical commitment and conduct which covered all spheres of life. For this, Hassan admits that it is difficult task to observe, study and 
analyze as although an aspect shows a single phenomenon, it has no simple synonym. Therefore, he argues that "just because people are religious in one way does not mean that they will be religious in other ways" (Hassan 2003: 40). Because of this, Hassan formulates five dimensions of Muslim piety which are the ideological dimension, the ritualistic dimension, the devotional dimension, the experiential dimension and the consequential dimension (Hassan 2003: 44-48).

Pertaining to the relation between veiling and piety, Sunesti's research found Hassan's dimension of ritualistic, devotional and consequential dominated women's view on their veiling (Sunesti 2007). Some women interviewed said that their veiling was an expression of their devotional to God while the other admitted as just an expression of ritualistic dimension so that unveiling for them was seen a normal and un-sinful, compared to devotional level which see veiling as an obligation while unveiling is breaking God's law. The consequential dimension confirmed the consequences of those different views toward their daily lives shaping their perspectives on life as well as their views on 'others'.

Concerning on the relation between veiling, piety and consumption, Jones sees that rather than constructing piety outside of consumption, Indonesian women nowadays construct their piety through its consumption. Therefore, she points that "devotion and consumption not only share qualities but also are dynamically coupled, each hinging on and promising to resolve problems posed by the other" (Jones 2010: 618). From this, the debates on the contestation between modesty and beauty confirms the reclaim of this relation to be more virtue rather than vanity. Thus, this paper looks at to what extent the debate on piety and beauty shape women through their consumption of veiling and its accessories by examining Jones finding of virtue rather than vanity. By looking at how members of Komunitas Muslimah Beauty construct the idea of piety and beauty, the debates on the current involvement of commodity into religiosity as well as religiosity into commodity can be tracked. 


\section{Women and Veiling}

The study of veiling in Islamic society has varied in terms of time frame as well as the findings. Following Rinaldo's macro and micro explanations, veiling can be understood from different points of view (Rinaldo 2010: 587-590). On the macro level, veiling was the form of patriarchal oppression against women (Mernissi 1987), a symbol of anticolonial and anti-Western identity widespread into many Islamic countries after Iranian Revolution in 1979 (Leila 1992; Nilufer 1996). as well as a part of the Islamic revival or Islamization such as that which occurred in Malaysia (Rinaldo 2010). However, Brenner, Gole and White tend to see the veiling phenomenon in their different countries as a way of women finding their own modern identity that opposes their parents' traditional practices as well as modern-secular ways of life (Brenner 2002; Nilufer 2002). For this they see that being modern and pious can go hand-in-hand. In more complex investigation, by studying the changes of veiling during forty-four period of the New Order and the Reform era, Hamdani sees that the changes of veiling in Indonesia has been heavily affected by the changing of social and political constellation in Indonesia at that time (Hamdani 2011).

In different focus, Amrullah points how the contemporary designs of Islamic fashion in Indonesia has been influenced from the form of Islamization brought by Indonesian from abroad and enriched by the invention of Indonesian designer in combining imported and local design of Islamic fashion (Amrullah 2008). More focusing on the women issues, Annisa portrays how women identity has been shaped by media in Indonesia. By analyzing the content of women magazine, Paras, she argued that the emergence of this magazine is trying to present "what is fashionable and trendy to a Muslima and promotes the idea that using halal cosmetics and wearing veil are not a barrier to looking beautiful in any situation" which make this idea is acceptable for Indonesian society (Annisa 2009). 
In the micro explanation, veiling can be understood as a woman's effort to define her self-identity through questioning why women veil. Mahmood and Smith-Hefner studies indicate that rather than viewing the Egyptian veiling as a symbol of anti-Western and other macro explanations, veiling in Egypt was simply understood as a kind of religious reason in which women want to be more pious (Mahmood 2005; SmithHefner 2007). In other word, Brenner called the veiling practices as a conversion of Javanese women from their bad past to the better or more religious future (Brenner 2002). Using ethnographical approach, Sunesti also inspects the different reasons for veiling of women in Yogyakarta and to what extent they affected veiled women's access to the public sphere (Sunesti 2007). The respondents argued that besides their motives of veiling was a conscious choice for being a pious person, they admitted that the influences from their surroundings were also much influential such as the Islamic discussion forums they joined and their interaction with current friends in their organizations.

The very new research on the veiling in micro analysis is conducted by Beta as she see it a redefinition of self-identity. By looking at the emergence of the new veiling namely bijabers community in Indonesia, she argues that bijabers community representing young urban middle class are actively redefined themselves through their preferences influenced by scene media. From their redefinition, Beta sees that this new trend has deconstructed the dichotomy between Islam and 'capitalist West' due to their reception to various available cultural references (Beta 2014). In more complex point of view, Jones portrays the emergence of the contradictory as well as mutually phenomena admits Indonesian society which are the rise of Islamic piety and the rise of consumerism cannot be explained from just one explanation, either religious or consumerism phenomenon, but it should be understood in the relation between faith, gender and materiality (Jones 2010). 
More relating to consumption focus, Hasan sees the wave of Islamic revival in Indonesia nowadays marked by the mushrooming of religious symbols, Islamic institutions and new life styles as well as religious commodification in many parts of Islamic products (Hasan 2009). Instead of looking at this commodification as a contestation between piety and commodity, he argues that the rising demands of Islamic products does not merely mean commercialization, but only an effort to package Islam to be accepted for broader market (Hasan 2009). In the more narrow concern, Willer studies how the commercialization of religion works in particular cosmetic product, Sunsilk Clean and Fresh shampoo. By viewing the issue from the contestation between religion and globalization in Indonesia leading to the development of consumer society and search for women identity, she argued that the product is not a just a shampoo to clean women hair. Yet, by using women with headscarf in the cover, she stressed that it implies the nowadays reality of the increasing of muslim women in Indonesia who are achieving more responsibility and power and continuously develop their potential to work and improve their quality of life as explicitly mentioned in its advertisement (Willer 2009).

Thus, the scholarly works on veiling have been argued having different focuses in dealing with veiling phenomenon in Muslim countries, from macro and micro perspectives. This paper will look at the debates on veiling in micro analysis which is how Muslim women in online public sphere define their notion of piety while at the same time acting as consumers of called 'Islamic commodities' produced by industrial capitalism. Although the discussion on the contestation of veiling between piety and commodity are discussed by scholars, focusing on how women construct their pious identity in online public discussion is still rare. This is why this paper is focused on this new kind of Indonesian democratic public sphere arguing that the involvement of Indonesians in the debate on the online public sphere has been significantly increased brought by the development of media technology and the rise of democracy. 


\section{From Veiling to Shopping}

The discussion topics in Komunitas Muslimah Beauty has varied from its early establishment to the most current discussion in May 2014. The variations range from the veiling issues discussion such as hijab hunt contest and hijab fashion to the discussion on Islamic daily practices and values as well as selling and buying products. From those 61 threads (topics), they are categorized into six categorizations which are shown in the table below. The discussion shows that the notion of women's piety has been contested with more modern and consumed culture nowadays in which members of the forum construct their identity through their 'Islamic' commodity.

Table 1

Topics Discussed in Komunitas Muslimah Beauty

\begin{tabular}{|l|c|}
\hline \multicolumn{1}{|c|}{ Major topic of discussion } & $\begin{array}{c}\text { Komunitas Muslimah Beauty } \\
\text { (N: 61 topics) }\end{array}$ \\
\hline A. Muslimah Beauty Events & 6 \\
\hline 1. Komunitas sillaturrabim & 2 \\
\hline 2. Wow muslimah beauty going to Paris & 1 \\
\hline 3. My mosque my home & 1 \\
\hline 4. Radio Dakwah broadcasting & 1 \\
\hline 5. Learning to working by online for \\
muslimah
\end{tabular}




\begin{tabular}{|c|c|}
\hline 2. Seven of fasting virtue & 1 \\
\hline $\begin{array}{l}\text { 3. Etiquette for giving opinion and } \\
\text { discussion in Islam }\end{array}$ & 1 \\
\hline 4. Ways to clean in Islam & 1 \\
\hline 5. An advice for muslimah & 1 \\
\hline 6. Contemporary islamic issues & 2 \\
\hline D. Veiling issues & 38 \\
\hline 1. Hijab fashion & 10 \\
\hline $\begin{array}{l}\text { 2. Why women will look more beautiful } \\
\text { when wearing hijab? }\end{array}$ & 1 \\
\hline $\begin{array}{l}\text { 3. Between hijab and thigh: which one } \\
\text { is the cheaper? }\end{array}$ & 1 \\
\hline 4. The band singer wearing hijab & 1 \\
\hline 5. Hijab Hunt contest & 25 \\
\hline Total & 61 \\
\hline
\end{tabular}

From the table can be seen that the discussion in Komunitas Muslimah Beauty is dominated by veiling issues having thirty-eight topics with twenty-five threads about hijab hunt contest followed by hijab fashion discussion with ten threads discussed. Beside the veiling issues, members of Komunitas Muslimah Beauty also discuss Islamic practices and values with various topics. The other categorizations the members have discussed are how to be a beautiful Muslim woman with the discussion about cosmetics, tips for making beauty with hijab as well as their offline activities categorization.

\section{Veiling Issues}

The discussion in this categorization is enlivened about the appeal to support hijab hunt contests by the participants who ask the other members to vote. This contest is a hijab contest held by Detik Forum followed by hundreds of women with hijab and then selected to fifty finalists to compete to be the top four of representative hijab women of Indonesia. The contestants came from many areas in Indonesia which competed to 
get votes from online members of Detik Forum. The final event for hijab hunt 2013 was held in Jakarta with four top winners who are:

Table 2

The Top four Finalists of Hijab Hunt 2013 of Muslimah Beauty

\begin{tabular}{|l|l|l|l|l|}
\hline & Name & Age & Vote & Tagline \\
\hline 1 & $\begin{array}{l}\text { Ayu Widya } \\
\text { Wulandari (East } \\
\text { Java) }\end{array}$ & 21 & $\begin{array}{l}1644 \text { votes } \\
(17.55 \%)\end{array}$ & $\begin{array}{l}\text { Hijab is my personality } \\
\text { but photography is my } \\
\text { hobby. Look fashionable } \\
\text { but still syar'i, bold to show } \\
\text { creativity, unique, and try } \\
\text { to be different to be an } \\
\text { inspiration for many people. }\end{array}$ \\
\hline 2 & $\begin{array}{l}\text { Najibah Rahma } \\
\text { (Central Java) }\end{array}$ & 20 & $\begin{array}{l}1435 \\
(15,13 \%)\end{array}$ & $\begin{array}{l}\text { Graceful, elegant and } \\
\text { fashionable with hijab and } \\
\text { of course in accordance } \\
\text { with Islamic sharia is my } \\
\text { hijab style. }\end{array}$ \\
\hline 3 & $\begin{array}{l}\text { Syarifah Gabriella } \\
\text { Harzegovina (Aceh) }\end{array}$ & 20 & $\begin{array}{l}1202 \\
(12,28 \%)\end{array}$ & $\begin{array}{l}\text { It is me. My hijab style is } \\
\text { simple, comfortable but } \\
\text { look stylish and interesting. }\end{array}$ \\
\hline 4 & $\begin{array}{l}\text { Ria Tito Anggraeni } \\
\text { (Riau) }\end{array}$ & 23 & $\begin{array}{l}572 \\
(6,03 \%)\end{array}$ & $\begin{array}{l}\text { fresh, cute and adorable. } \\
\text { That's me. I love anything } \\
\text { with soft colors and bright. } \\
\text { So it remains always look } \\
\text { fresh, cute and adorable. } \\
\text { Love it. }\end{array}$ \\
\hline
\end{tabular}

The table above confirms the emergence of a new trend of women and hijab in Indonesia which is one side want to be pious by wearing hijab and on the other side must be part of modern ways of life. The contest denotes the construction of contemporary pious women to formulate how to be Muslimah through the tagline they promote. The tagline of the winners shows that being nowadays Muslimah needs more than the devotion to God by wearing hijab but also the fashionable and elegant 
appearance based on what the trend looks like nowadays. The hijab which the winners promoted claimed representing their personality, being Muslimah and modern.

The discussion on the hijab hunt in Komunitas Muslimah Beauty attract pros and cons. The pros members said that the hijab hunt contest is very good effort to attract Muslim women to wear hijab. Because hijab has many choices models and more colorful, women can make their own style with the hijab. The cons members argue that the hijab hunt show the imperfect exemplars of un-Islamic hijab and this imperfect hijab will be potentially followed by other Muslimah. These two comments represent these pros and cons:

Are the hijab hunt contestants going to swaying on the stage in the final? Dessing with full colour and thik make up to attract men's eyes? Na'uzubillah! What are our generation going to be? This event should be not available. Our muslimah who previously wearing syar'i hijab because of this trend wearing a hijab which is just stuck on the head with shoulder which is still looked and the shape of the body is revealed. If you have been affected by the jews, do not damage the nation 's Muslim generation with your views. Remember what you do will be accountable in the afterlife. Sorry not patronizing, just a little bit disappointed with todays' new trend (Aphicia, 16 Agust 2013)

I ever watch the Muslim Beauty contest held by Detik. I did not find that swaying movement from the ladies. Their dres was also following syariah rules. The talent shown is that the creative talents and do not show off their own body's shape. Islam has ordered us to use perfume, shower and dress up not for attracting men. We should also be neat when we are going to mosque. But some of your suggestion could be logic, hijab should not show women's shoulder etc. For me, this event is good because can attract muslimah to wear hijab and proud of hijab (Barbie 762 777, 16 August 2013) 
The second most discussed topic in Komunitas Beauty Muslimah under the categorization veiling issues is hijab fashion. In the topic of 'all about muslim fashion', the members share information about the most updated hijab and muslim clothes. Some members share the updated hijab fashion from Indonesian designers such as Najua Yanti, Tuti Adib and Dian Pelangi. The other members share the muslim fashion worn by Indonesian artists such as Marshanda, Zaskia Adya Mecca and Elma Theana. One of members share their tips and tricks in wearing muslim clothes and differentiate them into different styles such as summer style, smart style, channel chic, Abaya chic and spring is in the air style. Another members suggest websites such as www.hijabstyle.blogspot.com and www. hijabstyle.co.uk to be references (forum.detik.com 2014).

The debate on the more ideological of wearing hijab arises in this categorization is a topic on 'why women will be more beautiful when they wear hijab' posted by alivalive in 16 October 2011. Alivalive posted that question and at the same time gave eighteen answers to her question. She answers why women look more beautiful when wearing hijab is because five of them are they cover their aurat (forbidden bodies to be seen), they will keep their morality, they can avoid a maksiat (the bad deeds), they can reduce men's desire, their hair will not be hung up with the fire and be burn in the afterlife. From fifty comments, thirty-one comments are strongly agreeing with the posts while about ten comments do not agree with the posts and questioning what alivalive means with her definition on hijab as beauty (forum.detik.com 2014). Some disagree comments can be seen below:

Sure, what means with this comment should be hijab which is following syariah rules (Haznastore, 27 January 2014).

Beauty is subjective. A beauty for a woman can be the contrary for the other. So, wearing hijab should not always mean beauty. Not always women wearing hijab is covering their aurat. Because you can 
also find women wear sexy and tight. (Rahmanahmad, 2 November 2011).

\section{How to be A Beautiful Muslimah}

Another discussion attracting many responses from the members is discussions under categorization of 'how to be a beautiful muslimah'. In this forum the members share their experiences and tips to make hijabers more beautiful. They discuss about how to treat hair and skin for hijabers as well as choosing cosmetics which should be halal. The members argue that halal cosmetics are a must. This is because cosmetics will relate to the purity of the body when they do ibadah as one of the members said:

As a Muslim we have to know exactly what items will go into our bodies. Obviously we will not know the composition or any substance that is in our cosmetics. What if they contain unclean and dangerous compounds? What if lotions, lipsticks, moisturizers, sunscreens, and other cosmetics contain ingredients that are unclean? And what about our daily prayers? While reading the Qur'an but still wear lotion unclean? Certainly unauthorized worship, is not it? Absolutely halal is my life. (ningaiyu, October 14, 2013)

Interestingly, some members suggest to use product with overseas brands as they recommend them as halal products and got halal certificate from MUI. On the other side, most members ask the administrator of the forum to give hijab tutorial including an information of halal cosmetics.

A discussion about how to be a beautiful Muslimah is also enlivened by the tips from a member to avoid skin blemish while wearing hijab due to Indonesian tropical weather. A member said that hijabers should at least doing six steps to prevent the skin blemish such as applying cosmetics to protect from ultraviolet as well as consuming a white skin supplement to give the skin nutrition. Some members appreciate this tip, but the others view that as not relevant for hijabers as one of the members said: 
I do not over use the cosmetics, therefore so far I save with my hijab and do not have blemish skin. All rely on our heart. (dini_pus, 14 April 2014)

For dini_pus, what is important for being muslimah beautiful is not what they should treat to their face or body, but what is in their heart, more on inner beauty.

\section{Muslimah Beauty Events}

Beside the discussion within the forum, Muslimah Beauty members also hold an offline activity such as cleaning the mosques and meeting and gathering. One of the prestigious events followed by Muslimah Beauty members is the joining of the winner of Muslimah Beauty 2011, Dika Restiyani, in International of The Muslim World on December 2011 in Paris France with several Muslim fashion designers (forum.detik.com). Most members see this event as positive activity to spread Indonesian Muslim fashion into the world.

Another offline activity is cleaning masjid called 'Masjidku Rumahku' event. This community service was held in Darussalam Mosque in Menteng South Jakarta by Muslimah Beauty Foundation and followed by the winners of Hijab Hunt 2011 of Muslimah Beauty and some members. They said that this event is aiming to invite Indonesian people to be more paying an attention to mosques as mosques are a primary place to improve Muslim's morality (forum.detik.com 2014).

\section{Online Shopping}

Although there is a warning from the administrator of the forum that members are prohibited to sell anything within the forum, most of the members explicitly suggesting the other members to open the links they promote. Most of the links lead members to particular selling website with various products offer such as Muslimah clothes, veil, and cosmetics. For this, discussion forum can be an alternative to sell products considering 
the members have regularly asked an updated information about Muslim fashion and its accessories.

\section{Women Religiosity through Consumption}

The debates in Komunitas Muslimah Beauty confirms the contestation between piety and beauty through member's discussion on various issues they are discussing. The discussion come up with the idea of how to be nowadays Muslimah, the debates within this identity's construction and negotiation as well as the idea of globalizing current Muslimah identity.

\section{Who are We? A Muslimah Identity Construction}

The debate dominated by the continuously members' update on the new style of hijab shows how they have been actively defining and constructing their identity to be the most currently Indonesian Muslimah. This definition of Islamic identity cannot be released from what they see about being Muslimah and modern showed by various references from modern media. The discussion indicates that the members have been mostly defining hijabers as simply as wearing it as an Islamic order for Muslim with very simple argumentation such as 'I am wearing it because my religion require women to wear it'. As a consequence, the interpretation on how to be hijabers look like is also vary. What is expressing in Komunitas Muslimah Beauty is that most members try to negotiate their identity of being muslimah with popular and modern expression as can be seen representatively from the taglines of the hijab hunt winners which most of them mention about syar'i, fashionable and attractive. Thus, being nowadays Muslimah can be argued a combination of hijab+fashionable+energic. Although this definition has attracted debate on questioning the syari bijab which is simple, modest and loose, most members do likely agree that being bijabers should be fashionable outlook. 
Following Riaz Hassan's piety categorization, the religious expression of what the members are portraying is hardly claimed. This is because what can be known from their expression is just what they write in the online forum which is very limited reasons and expression appeared. However, analyzing what they mostly said it can be argued that the members of Komunitas Muslimah Beauty show both ritualistic and devotional dimensions. Ritualistic dimension can be argued showed by their very simple and superficial reasons in responding the question of why they wear hijab. Some members said that they wear it because they are just simply Muslimah which God order them to wear. Some members argue little bit more deeply reflection pointing that syari hijab and appearance is a must for Muslimah rather than just simply wearing it showing more devotional dimension of piety. They also argue that showing a submission to God is by wearing a modest hijab rather than more colorful and stylish one based on what hijab means for Muslimah. Because of this, these few members regularly reject the ideas of being modern and fashionable hijab promoted by the dominant hijabers members.

Following this contestation, a Muslimah identity in the online debate has shown a continuously defined and constructed. One group of Muslimah construct their identity through what they consume while the other try to keep their traditional expression of being Muslimah by rejecting the consumptive ways of being Muslimah. The construction continues as the members are very actively trying to connect their consumption to their choices of veiling. For this, what Jones (2010) argued that Indonesian Muslimah nowadays tend to construct piety through its consumption rather than outside of consumption seems to be true. Although the contestation has still emerged, the direction is marked to be more adapting piety into consumption and vice versa. 


\section{Globalizing Piety: the Continuously Negotiation}

Since more people communicate actively through the online sphere which is borderless of time and space, the locality idea within the discussion is being globalized. This is because every people in different space and time can contribute in responding the discussion and bringing the idea to the broader sphere where they live. The discussion in Komunitas Muslimah Beauty shows this in which a topic can be discussed for about three years by the same or different members. For this, an idea can be continuously updated and debated. Through two dimensions of globalization showed in the forum, members of the forum have continuously negotiated their identity by continuously formulating their self-definition of piety as well as adapting to the material expression through their consumption.

The first globalization appeared in the forum is that the members has been not only consuming the commodity offered by Indonesian exemplars, they also import and adopt the style of hijab from Muslimah fashion abroad. This can be seen from some members who posted the fashion worn by Muslimah in Brithish and Dubay and other countries as well as comment how this can be adopted to Indonesian fashion. This adaptation shows the negotiation of Indonesian Muslimah identity in formulating the more fitted Muslimah expression amidst the attack of newest modern style of fashion through the scene media. Since they have continuously posted and commented to this change and some members show their adaptation through their pictures shared in the forum, they has been argued experiencing a regular negotiation of their identity in this sense.

The second globalization is the globalizing the idea of piety constructed within the forum into the members. Since they have been doing simultaneously defining and constructing their piety within the forums, they do together in spreading their ideas into other members and even the new members who improve significantly day to day. An argument 
for this is that the piety they constructed and confirmed can be adopted by broader Muslimah in broader places and time as they can also contribute to this negotiation and construction anytime and anywhere.

\section{Conclusion}

The discussion within Komunitas Muslimah Beauty of Detik Forum in Detik.com confirms the continuously construction and negotiation of veiling, piety and commodity among the online forum members. The various topics as well as the comments appeared show the complexity in understanding the veiling and piety of Indonesian Muslimah when it has a contact with material senses. The findings is not only confirming what Jones argue that Muslimah nowadays negotiate their piety through consumption, but also challenging the idea that piety and commodity has been intertwined each other so that blurring who dominates whom. Finally, as Komunitas Muslimah Beauty is an online sphere which is borderless in time and space, it brings the idea of globalizing the debate into the broader audiences. Therefore, the construction and negotiation of piety and commodity has moved from local debate to more global contestation.

\section{References}

Ahmed, Leila. 1992. Women and Gender in Islam: Historical Roots of a Modern Debate. New Haven: Yale University Press.

Amrullah, Eva F. "Indonesian Muslim Fashion Styles and Designs", in ISIM, Review 2/Autumn 2008.

Annisa, Firly. 2009. "Representation of fashion as Muslima Identity in Paras Magazine", in Johanna Pink (ed.), Muslm Societies in the Age of Mass Consumption: Politics, Culture and Identity between the Local and the Global. UK: Cambridge Scholars Publishing. 
Barton, Matthew D. 2005. "The Future of Rational-Critical Debate in Online Public Spheres", Computers and Composition, 22:179.

Brenner, Suzanne. 1996. "Reconstructing self and society: Javanese Muslim women and "the veil," American Ethnologist 23 (24).

Hamdani, Deni. 2011. Anatomy of Muslim Veils: Practice, Discourse and Changing Appearance of Indonesian Women. Germany: Lap Lambert Academic Publishing.

Hasan, Noorhaidi. 2009. “The Making of Public Islam: Piety, Agency, and Commodification on the Landscape of the Indonesian Public Sphere", Contemporary Islam, 3.

Hassan, Riaz. 2003. Faithlines: Muslim Conceptions of Islam and Society. Pakistan: Oxford University Press, 2003.

Jones, Carla. 2007. "Fashion and Faith in Urban Indonesia", in Fashion Theory, Volume 1, Issue 2/3.

Jones, Carla. 2010. "Materializing piety: Gendered anxieties about faithful consumption in contemporary urban Indonesia," American Ethnologist, Vol. 37, No. 4, November.

Mahmood, Saba. 2005. The Politics of Piety: The Islamic Revival and the Feminist Subject. Princeton: Princeton University Press.

Mernissi, Fatima. 1987. Beyond the Veil: Male-Female Dynamics in Modern Muslim Society. Bloomington: Indiana University Press.

Nilufer, Gole. 1996. The Forbidden Modern: Civilization and Veiling. Ann Arbor : University of Michigan Press.

Porter, David (ed.). 1997. Internet Culture. New York: Routledge.

Rinaldo, Rachel. 2010. "Women and Piety Movement", in Bryan S. Turner (ed.), The New Blackwell Companion to the Sociology of Religion. UK: Wiley-Blackwell.

Rinaldo, Rachel. 2013. Mobilizing Piety: Islam and Feminism in Indonesia. New york: Oxford University Press.

Smith-Hefner, Nancy J. 2007. "Javanese women and the veil in postSoeharto Indonesia”, Journal of Asian Studies, 66 (31). 
Sunesti, Yuyun. 2007. "Tubuh dalam Persepsi Perempuan Berjilbab di Yogyakarta (Sebuah Kajian Etnografi Feminis)", Tesis, CRCS UGM Yogyakarta, 2007.

White, J. 2002. Islamist Mobilization in Turkey: A Study in Vernacular Politics. Washington: University of Washington Press.

Willer, Ragnar K. 2009. "The Re-Spiritualization of Consumption or the Commercialization of Religion: Creativity, Responsibility, and Hope: The Case of Sunsilk Clean and Fresh in Indonesia", in Johanna Pink (ed.), Muslm Societies in the Age of Mass Consumption: Politics, Culture and Identity between the Local and the Global. UK: Cambridge Scholars Publishing.

\section{Internet Sources}

iklanbaris.detik.com, accessed on December 9, 2009.

id.shvoong.com, accessed on December 9, 2009.

forum.detik.com, accessed on December 9, 2009.

forum.detik.com/?ctfr, accessed on May 12, 2014.

forum.detik.com/komunitas-f1.html, accessed on May 12, 2014.

forum.detik.com/silaturahmi-komunitas-muslimah-beauty-t297818.html, accessed on May 12, 2014.

forum.detik.com/muslimah-beauty-masjidku-rumahku-t357101.html. accessed on May 12, 2014. 
DINIKA, Volume 4, Number 3, September - December 2019 